The BDJ News section accepts items that include general news, latest research and diary events that interest our readers. Press releases or articles may be edited, and should include a colour photograph if possible. Please direct your correspondence to the News Editor, Arveen Bajaj at the BDJ, The Macmillan Building, 4 Crinan Street, London N19XW or by email to bdj@bda.org

\section{New Vice Dean appointed}

The Faculty of General Dental Practice (UK) has announced the election of Richard Hayward as its Vice Dean. Dr Hayward spent 20 years in practice in the Royal Navy, where he took advantage of the postgraduate education opportunities on offer. He became a founder member of the FGDP(UK) in 1992 and is a long-standing board member. Previously Vice Dean in 1999, he has recently chaired the Faculty's examinations committee. He is an enthusiast for improving the quality of dental care for all patients treated in the primary sector.

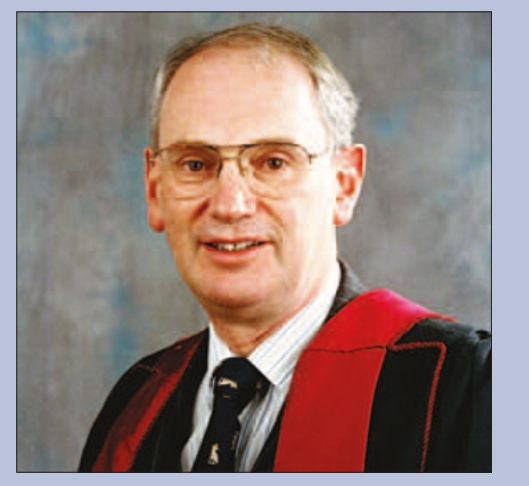

\section{Putting patients first}

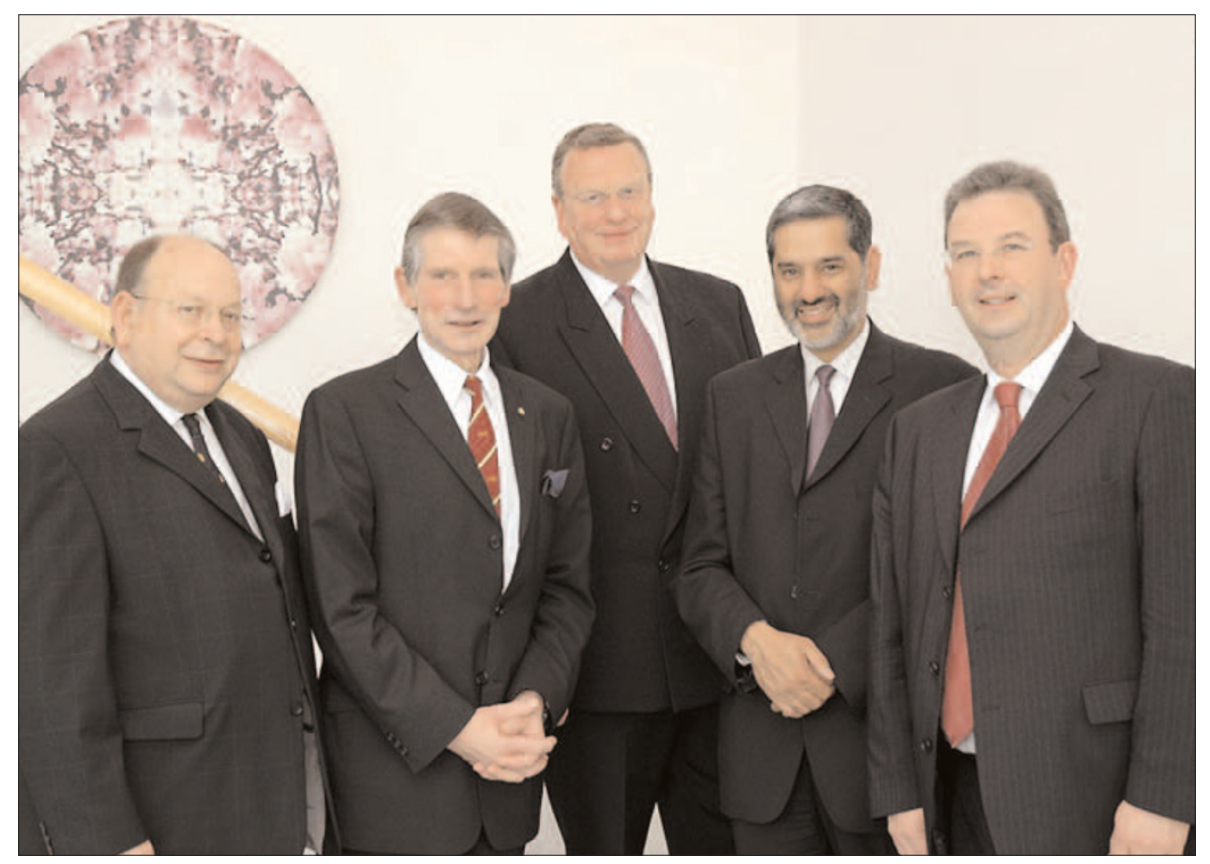

Public protection is vital in developing special interests in general practice as a parallel to the academic or hospital route, was the message delivered to an audience at the Manchester Dental Education Centre at the annual NHF Wilson Lecture in June. Professor John Lowry's address included pointers about the future of specialisation and the importance of being able to prove competence in any special interest pathway. Professor Lowry is pictured second from left with (left to right) Josef $L$ Rich OBE, MANDEC Chairman, Professor NFH Wilson, Professor Raman Bedi, Chief Dental Officer of England and Mr H Mathewson, President of the General Dental Council.

\title{
Positive practice in mental health
}

People who work in mental health services are set to be recognised in the third national NIMHE Positive Practice Awards 2005. The awards acknowledge people, teams and organisations whose work in mental health services have made a positive impact on people's lives.

The event organisers, the National Institute for Mental Health in England (NIMHE), are urging projects, teams or organisations of all sizes working in mental health services in the public, private and voluntary sectors who feel they have something to share to apply, as the awards aim to capture examples of any practice which has made a positive impact on peoples lives. There are two awards for individuals - Making a Difference and the Volunteer Manager and all others are for teams or organisations. This year's award categories include older people and mental health, child and adolescent mental health, mental health care in prisons and learning disability and mental health.

Talking about the significance of the awards, Positive Practice group chair, and founder of the awards, Tony Russell commented, "I think it is essential to award people who work in a difficult field. We need to identify positive practice, to reward it and to disseminate it so that examples spread across our services."

The awards ceremonies will be held in London on November 28th. The closing date for applications is September 30th. For further details about the awards and application forms

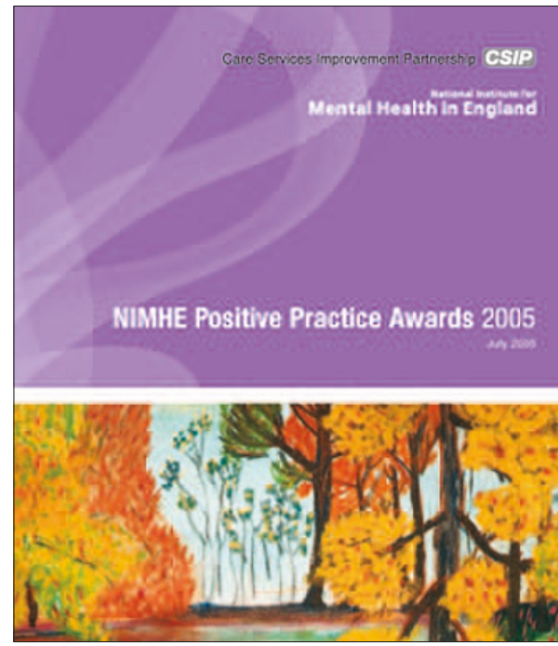
visit www.nimhe.org.uk. 
August 2005

FDI World Dental Congress 2005

Date: 24-27.08.05

Venue: Palais de Congrès, Montréal

Email: congress@fdiworldental.org

www.fdiworldental.org

\section{September 2005}

Oral health through public health: Professor

Aubrey Sheiham, A celebration of his work

Date: 5-6.09.05

Venue: University College London

www.ucl.ac.uk/dph

The Irish Endodontic Society 12th Biennial

Congress of the European Society of

Endodontology

Date: 15-17.09.05

Venue: Dublin

Tel: +35316799144

Fax: +35316486197

www.esedublin2005.com

\section{October 2005}

BDA Metropolitan Branch: Spot the

Composite

Date: 01.10 .05

Venue: British Dental Association, London Tel: 01943604400

British Dental Trade Association

International Dental Showcase 2005

Date: 6-8.10.05

Venue: NEC Birmingham

Tel: 08702413365

www.dentalshowcase.com

146th American Dental Association Annual Session and Technical Exhibition

\section{Date: 6-9.10.05}

Venue: Pennsylvania Convention Center, Philadelphia

Email: annualsession@ada.org

www.ada.org

DenTech China 2005

Date: 26-29.10.05

Venue: Shanghai Everbright Convention

\&t Exhibition Center, Shanghai

Tel: 86-21-6294 6966

Fax: 86-21-6280 0908

Email:mail@showstar.net

www.dentech.com.cn

\section{November 2005}

2nd European Congress on the

Reconstruction of the Periodontally

Diseased Patient

Date: 25-27.11.05

Venue: Radisson SAS Scandinavia Hotel, Copenhagen

Email: kongress@quintessenz.de

www.quintessenz.de/ecrp

\section{Targeting mouth cancer}

Cancer Research UK is to launch a three-year campaign in November to raise awareness of the risks and symptoms of mouth cancer, with funding from the Department of Health. The new campaign will focus on raising awareness of the early signs of mouth cancer and the importance of early detection. According to the charity, around 4,400 people get mouth cancer every year in the UK and nearly 1,600 die from the disease yet most cases are preventable. The primary risk factors for the disease are tobacco and excessive alcohol consumption.

The charity adds that evidence shows early detection of mouth cancer can significantly improve the chances of successful treatment - raising five-year survival rates from around 50 to 90 per cent. Sara Hiom, Head of Health Information at Cancer Research UK says, "Although mouth cancer is less common than melanoma, roughly equal numbers of people die from these diseases annually. This reflects the poorer survival rates for mouth cancer. Many people do not know enough about mouth cancer and its early signs for it to be detected in good time. We hope that improving awareness of the disease will raise survival rates."

The Department of Health is giving Cancer Research UK £100,000 a year for an initial three years to run the new campaign and will rely in its first year on a PR campaign, to be launched during Mouth Cancer Awareness Week (13-19 November). The charity will also make extensive use of case studies to illustrate its message and reach target audiences through lifestyle publications. It will also focus on 'at-risk' groups including people who smoke and/or drink heavily, those over the age of 40 and people who are not registered with a dentist.

The campaign will include messages to dentists, doctors and pharmacists, who can play key roles referring patients with suspected early signs of mouth cancer to specialists.

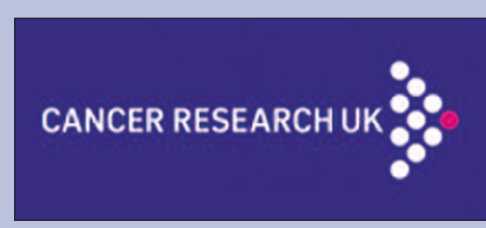

The Chief Dental Officer for England, Professor Raman Bedi, said, "This campaign is timely because under new contractual arrangements for NHS dentistry, to be introduced next April, dentists will undertake a more extensive assessment of their patients' oral health."

\section{New measures for GDC announced}

New powers for the General Dental Council (GDC) to protect patients have been announced by Health Minister Rosie Winterton. These include measures to tackle problems highlighted in a report on the private dentistry market in the UK by the Office of Fair Trading (OFT). Patients complained that they were not given adequate information to make informed choices about their treatment and often did not know how much their treatment is going to cost.

The Order, made under Section 60 of the Health Act, will allow the GDC to establish a complaints scheme for non-NHS patients to complain about their dental care. For example, dentists are expected to agree a patient's treatment costs in advance. If the patient then finds that, without their consent, the costs substantially exceed this agreed amount, the new measures give the patient the means to complain.

This Order will also empower the GDC to address the other concerns highlighted in the OFT report by introducing compulsory indemnity cover for dentists before registration, so that dentists who are found to have harmed patients are insured and able to pay compensation. It will givie the GDC the power to extend regulation to other professionals working within dentistry, including dental technicians and nurses and modernise the Council's 'fitness to practise' procedures for dealing with misconduct and ill health amongst dental professionals. It will also allow the Council to introduce new procedures to tackle problems of poor performance.

Rosie Winterton said, "These measures will make sure patients get a fair deal and clear information when they receive dental treatment. Through these new powers, the General Dental Council is better placed to assure the quality of care that patients receive and provide a more robust and effective complaints system to take early action when things go wrong." She added that ensuring dentists had proper indemnity cover before they registered was an important extra protection for patients and could avoid cases in which patients have sued for damages and then found the dentist could not pay. 


\section{Futuristic use for baby teeth}

Baby and wisdom teeth, along with jawbone and periodontal ligament, could be used as a source for stem cells that could be 'banked' for future health needs, according to a National Institutes of Health researcher who spoke at the American Dental Association's national media conference in the USA last month.

According to Dr Pamela Gehron Robey, of the National Institute of Dental and Craniofacial Research of the National Institutes of Health, USA, the stem cells harvested from the pulp layer inside the teeth, jawbone and periodontal ligament, may one day correct periodontal defects and cleft palate, and may help restore nerve cells lost in diseases such as Parkinson's. She claimed that the stem cells had the potential to save injured teeth and grow jawbone, while regenerating an entire tooth would also one day be possible. She added that in the future stem cells from teeth and the jawbone might be used to correct cleft palate, sparing children multiple surgeries.

"As long as a cell has a nucleus, anything is possible. The stem cells from the jawbone and teeth share a common origin with nerve tissue and with the proper cues, researchers may be able to encourage them to form nerve-like tissue which may restore cells that make dopamine, but much more work is needed," Dr Robey states.

In time, individuals may be able to bank their own stem cells from baby and wisdom teeth, similar to the way umbilical cord blood is stored. According to Dr Robey, the viability of stem cells derived from baby teeth is determined by when the tooth comes out. The longer a loose tooth is left in the mouth to fall out on its own, the less viable it is as a source of stem cells.

To extract the stem cells from teeth, researchers can remove the periodontal ligament, drill into the tooth to remove the crown and then extract the pulp which is placed in an enzyme solution to release the stem cells. From the jawbone, cells can be isolated by collecting marrow following a tooth extraction, for example, or by biopsy.

However, Dr Robey cautions that it may be years before research in the field reaches the point where it would be practical for people to start banking their teeth for stem cells, but added, "When you think about it, the teeth children put under their pillows may end up being worth much more than the tooth fairy's going rate."

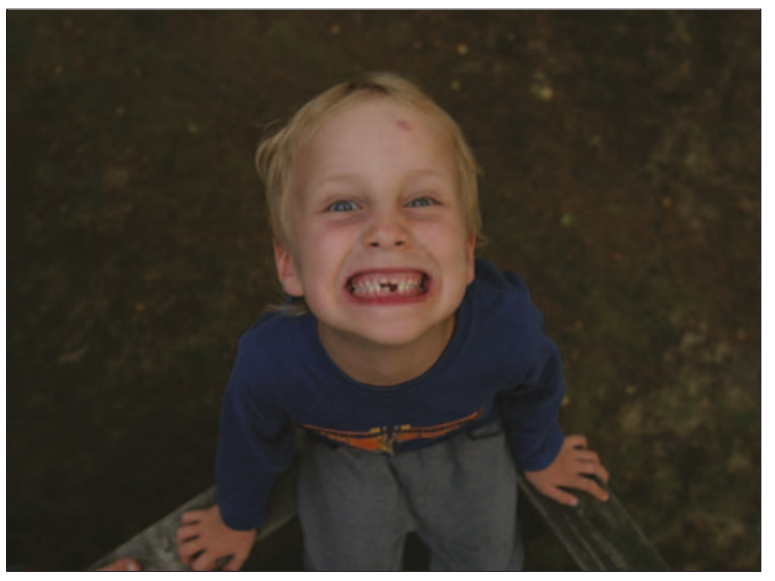

\section{New dental charges system outlined}

The government has announced the next steps to modernise and reform NHS dentistry which are set to promote good oral health, set out a new dental charges system and outline a new NHS contract for dentists. The proposals will build on the current phase of the modernisation which included recruiting the equivalent of 1,000 NHS dentists, increasing undergraduate training places and devolving funding to local Primary Care Trusts.

A new dental charges system will replace the fee scale system where dentists have to claim separately for each item of treatment they carry out. This means that dental patients will know exactly how much they are being charged before they receive their treatment.

The new system groups all dental treatment into three bands and is intended to make charges fairer and less confusing for patients, and less bureaucratic for dentists to administer. Under the new dental charging system the maximum cost of NHS dental treatment would be reduced by more than half and existing exemptions, including children under 18 and those on income related benefits would be maintained.

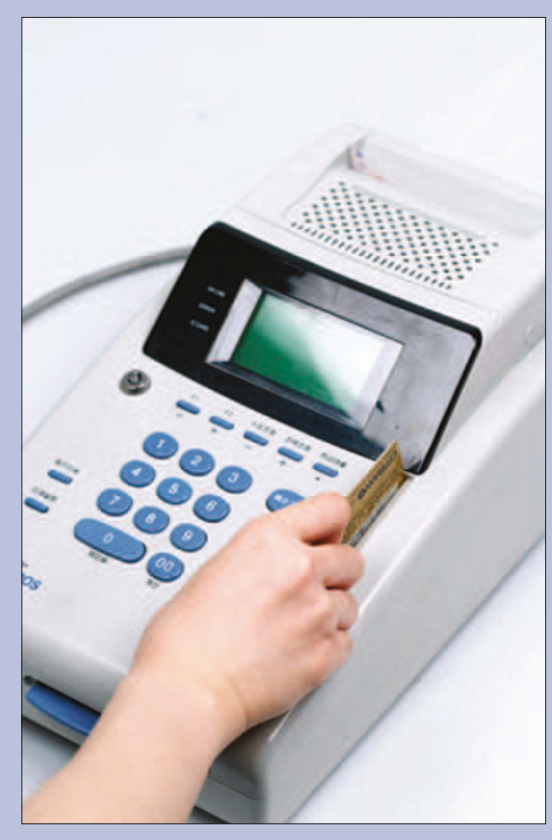

The three payment bands, which are outlined in a consultation paper are Band 1 which covers preventative dental work, such as scaling and polishing and the provision of oral health advice at $£ 15.00$, Band 2 which covers simple treatment, for example fillings and extractions set at $£ 41.00$ and Band 3 which covers complex treatment, such as bridgework, crowns, or dentures set at $£ 183.00$.

The traditional basic 'check up' will be replaced with an oral health assessment, which will include any necessary x-rays, scale and polish, and oral health advice. Patients currently exempt from paying dental costs, such as children, expectant and nursing mothers, and those on income related benefits, will continue to receive free dental care.

According to the government, the system reflects recent guidance from the National Institute for Clinical Excellence (NICE) which advises that patients be recalled between three and eighteen months depending on their clinical need - as opposed to the traditional six monthly recall.

In addition, Rosie Winterton outlined new contractual arrangements for dentists which will come into effect in April 2006. The government hopes the new contract will encourage the promotion of oral health and remove dentists from the 'drill and fill' treadmill by paying them for the overall service they provide to a patient, rather than for each of the individual treatments they carry out.

She commented, "Those with poor oral health or from low income backgrounds are often discouraged from seeking dental treatment due to the prohibitive costs. These patients will benefit from more affordable treatment, as the proposed Band 3 costs are less than the current £384 maximum charge." 